\title{
Respon Perkecambahan Benih Padi (Oryza sativa L.) Varietas Lokal SiGadis Hasil Iradiasi Sinar Gamma
}

\author{
Irine Prabhandaru dan Triono Bagus Saputro \\ Departemen Biologi, Fakultas Ilmu Alam, Institut Teknologi Sepuluh Nopember (ITS) \\ e-mail: trionobsaputro@bio.its.ac.id
}

\begin{abstract}
Abstrak-Padi Bengawan merupakan klon varietas lokal yang potensial karena memiliki wangi yang khas dan memiliki rasa yang enak, beberapa klon varietas ini memiliki ketahanan terhadap penyakit blas leher, contoh varietas padi Bengawan adalah SiGadis. Tetapi, padi varietas lokal SiGadis tidak tahan kekeringan sehingga perlu dilakukan peningkatan status ketahanan. Salah satu cara yang dapat dilakukan untuk meningkatkan ketahanan varietas lokal adalah melakukan induksi mutasi iradiasi sinar gamma. Dosis iradiasi sinar gamma yang diberikan pada benih padi adalah 0 Gy, 100 Gy, 200 Gy, dan 300 Gy. Klon varietas SiGadis hasil iradiasi sinar gamma dianalisis dengan Anova one way dilanjutkan dengan uji DMRT pada taraf $5 \%$. Iradiasi sinar gamma pada benih tanaman padi varietas SiGadis memberikan pengaruh yang tidak signifikan. Peningkatan dosis iradiasi menurunkan daya berkecambah dan keserempakan tumbuh benih. Sampel kontrol dan 100 Gy didapatkan hasil yang sama yaitu sebesar $80 \%$, sedangkan 200 Gy dan 300 Gy terjadi penurunan secara berturut-turut sebesar $70 \%$ dan $60 \%$. Sedangkan parameter laju perkecambahan kontrol dan perlakuan 300 Gy didapatkan hasil yang sama yaitu selama 4 hari, sedangkan pada 200 Gy selama 4 hari 20 menit dan 100 Gy didapatkan hasil yang paling lama yaitu 4 hari 30 menit. Iradiasi sinar gamma dapat memberikan informasi mengenai ketahanan varian baru dari benih padi varietas lokal SiGadis.
\end{abstract}

Kata Kunci-Iradiasi Sinar Gamma, Padi Varietas SiGadis, Perkecambahan.

\section{PENDAHULUAN}

$\mathrm{P}$ ADI (Oryza sativa L.) merupakan salah satu tanaman budidaya terpenting dalam peradaban manusia. Pada saat ini produksi padi dunia menempati urutan ketiga dari semua serealia setelah jagung dan gandum [1]. Tanaman padi (Oryza sativa L.) merupakan tanaman pangan utama di Indonesia yang dapat menyumbangkan 40-80\% kalori dan $45-55 \%$ protein. Padi termasuk dalam genus Oryza. Padi di Indonesia memiliki 25 spesies Oryza dengan dua subspesies yaitu Indica (padi bulu) dan Sinica (padi cere). Padi yang ada sekarang merupakan persilangan antara Oryza officianalis dan Oryza sativa [2].

Indonesia memiliki keragaman genetik padi yang besar. Jenis padi dibedakan menjadi beberapa subspesies diantaranya adalah jeponica, indica, dan javanica. Padi jenis bengawan adalah bagian dari subspesies javanica. Padi Bengawan merupakan varietas lokal yang potensial dan memiliki wangi yang khas dan memiliki rasa yang enak. Asal perilangan padi padi varietas lokal SiGadis adalah dari Benong, termasuk golongan cere (indica), umur tanaman berkisar antara 140-145 hari, bentuk tanamannya agak tegak, tingginya berkisar antara $145-150 \mathrm{~cm}$. Padi padi varietas lokal SiGadis memiliki anakan produktif yang tergolong banyak. Warna daunnya hijau dengan muka daun bertekstur kasar dan lebar. Posisi daun agak tegak. Bentuk gabah panjang dan gemuk dengan warna gabah uning dengan ujung gabah ungu, padi klon ini sedikit mudah rontok dan sedikit mudah rebah, mengandung kadar amilosa sebesar $28 \%$ [3].

Padi klon varietas SiGadis memiliki ketahanan terhadap bakteri hawar daun (Xanthomonas oryzae), peka terhadap penyakit blas (Pyricularia oryzae) dan tidak peka terhadap lamanya penyinaran, sehingga perlu dilakukan peningkatan status ketahanan. Salah satu cara untuk meningkatkan status ketahanan adalah dengan induksi mutasi dengan iradiasi sinar gamma [3].

Induksi mutasi menggunakan iradiasi menghasilkan mutan paling banyak (sekitar 75\%) bila dibandingkan menggunakan perlakuan lainnya seperti mutagen kimia. Perubahan yang ditimbulkan karena pemberian mutagen baik fisik maupun kimia dapat terjadi pada tingkat genom, kromosom, dan DNA [4]. Teknik mutasi iradiasi sinar gamma lebih menguntungkan karena prosesnya yang cepat, tujuan dari teknik mutasi iradiasi sinar gamma ini agar dapat memperbaiki satu atau dua sifat tanaman dan dapat menimbulkan sifat baru [5].

Teknik iradiasi yang digunakan untuk peningkatan variasi telah banyak dilakukan mulai dari mikroalga hingga tumbuhan tingkat tinggi. Pemberian iradiasi pada Nannochloropsis sp. iradiasi mampu meningkatkan kandungan lipid [6], Padi [7]. Peningkatkan ketahanan tanaman terhadap cekaman abiotik telah banyak dilakukan pada berbagai tanaman jagung [8][9], dan [10] untuk mendapatkan kalus yang memiliki sifat ketahan terhadap cekaman salinitas.

\section{METODE PENELITIAN}

\section{A. Waktu dan Tempat Penelitian}

Penelitian ini dilakukan pada bulan Oktober 2016 hingga Januari 2016 bertempat di Laboratorium Biosains dan Teknologi Tumbuhan, Departemen Biologi, Institut Teknologi Sepuluh Nopember, Surabaya dan iradiasi benih padi dilakukan di Pusat Aplikasi Teknologi Isotop dan Radiasi (PATIR), Badan Tenaga Nuklir Nasional (BATAN) dengan dosis iradiasi sebesar 0 Gy, 100 Gy, 200 Gy, dan 300 Gy.

\section{B. Prosedur Kerja}

Penelitian dilakukan sesuai dengan metode sebagai berikut: 
1. Sterilisasi Benih, Alat dan Bahan

Gabah dikupas terlebih dahulu kulit bijinya lalu diperoleh benih. Benih yang telah diberi iradiasi dengan sinar gamma direndam selama 4 jam dengan air. Setelah itu, benih dimasukkan ke dalam larutan sabun cair tersebut dan ditunggu selama 15 menit, kemudian benih di bilas dengan akuades, benih direndam dalam antifungal (1,5 gr/100 ml akuades steril) ditunggu 15 menit, lalu dibilas dengan akuades steril sebanyak 3x didalam LAF. Alat dan bahan disterilisasi dengan autoklaf. Khusus bahan seperti tissue, kertas saring dan kapas disterilisasi terlebih dahulu dengan dibungkus ke dalam plastik tahan panas kemudian di autoklaf dengan suhu $121^{\circ} \mathrm{C}$ tekanan 1.5 atm selama 15 menit. Alat dan bahan yang telah disterilisasi diletakkan ke dalam LAF.

\section{Pengujian Vigoritas dan Viabilitas Benih}

Pengamatan uji vigoritas dan viabilitas benih dilakukan dengan menggunakan metode tanam pada kapas. Umumnya metode tanam pada kertas menggunakan cawan Petri sebagai wadah untuk mengecambahkan benih. Prosedur kerja uji tanam pada kertas menurut Lesilolo, et al., [11], sebagai berikut, benih murni yang sudah disortir dengan perendaman diambil secara acak. Kertas saring sebanyak tiga lembar disiapkan untuk tiap jenis benih yang diujicobakan. Tiap percobaan diulang sebanyak lima kali. Kertas saring diguntung bentuk lingkaran seperti bentuk dasar cawan Petri kemudian dimasukkan dan basahi kertas dengan air. Setelah kertas telah basah secara merata, air ditiriskan hingga tidak ada lagi air yang menetes. Benih ditanam sebanyak empat benih tiap ulangan diatas kertas saring. Cawan Petri ditutup untuk mencegah kontaminasi. Pengamatan dilakukan terhadap kecambah normal, kecambah abnormal, benih keras, benih segar tidak tumbuh dan benih mati tiap hari selama 7 hari pengamatan. Kriteria untuk menilai hasil pengujian daya kecambah adalah sebagai berikut:

a. Kriteria kecambah normal $(\mathrm{N})$ :

1) Akar primer tumbuh dengan kuat dengan akar-akar sekunder. Sedangkan akar seminal sekunder yang tumbuh dengan kuat, 2-3 akar. Adakalanya akar seminal primer tidak tumbuh, tetapi paling sedikit 2 akar seminal sekunder harus tumbuh dengan kuat.

2) Daun primer tumbuh sepanjang koleoptil dan telah tersembul keluar dari koleoptil. Dalam keadaan demikian, daun harus kelihatan sehat. Plumula dapat pula melengkung tumbuhnya asal tidak busuk.

3) Perkembangan hipokotil yang baik sempurna tanpa ada kerusakan pada jaringan -jaringannya.

4) Memiliki satu kotiledone untuk kecambah dari monokotil dan dua bagi dikotil.

5) Untuk benih tanaman dengan tipe perkecambahan epigeal dikatakan normal apabila panjang akar $4 \times$ panjang benih dan mempunyai perkembangan struktur yang normal.

6) Kecambah yang busuk karena ifeksi oleh kecambah lain masih dianggap normal, bila bagian - bagian penting dari kecambah semua ada [12][13].

b. Kriteria kecambah abnormal (AB):

1) Tidak tumbuh akar primer atau sekunder atau jika tumbuh,akarKertsebut lenłahobox, pendek.
2) Tidak tumbuh daun pertama dan koleoptil tidak berwarna. Adakalanya plumula tumbuh berwarna putih atau membusuk

3) Kecambah yang rusak, tanpa kotiledon, embrio, yang pecah dan akar primer yang pendek.

4) Kecambah yang bentuknya cacat, perkembangan lemah atau kurang seimbang dari bagain - bagian yang penting [12][13].

\section{Benih Mati (BM)}

Benih yang busuk sebelum berkecambah atau tidak tumbuh setelah jangka waktu pengujian yang ditentukan, tetapi bukan dalam keadan dorman [13].

\section{Benih Keras (BK)}

Benih yang pada akhir uji daya kecambah masih keras karena tidak meyerap air disebabkan kulit impermiabel, dianggapa sebagai benih yang berkulit keras harus disebutkan tersendiri dalam analisa [13].

\section{Benih Segar Tidak Tumbuh (BSTT)}

Benih yang tidak tumbuh sampai akhir dari pengujian, tetapi masih mempunuai kemampuan untuk tumbuh menjadi normal. Benih jenis ini sebetulnya mapu menyerap air selama proses penujian tetapi mengalami hambatan untuk proses perkembangan selanjutnya [13].

Parameter viabilitas yang akan digunakan dalam penelitian ini adalah:

\section{a. Daya kecambah}

Daya berkecambah ditentukan dengan menghitung jumlah benih yang berkecambah normal selama jangka waktu 7 hari dengan menggunakan rumus ISTA (1972) sebagai berikut:

$$
\mathrm{DK}=\frac{\mathrm{JK}}{\mathrm{JC}} \times 100 \%
$$

\section{Keterangan:}

DK = Daya perkecambahan.

JK = jumlah kecambah normal yang dihasilkan.

JC = jumlah contoh benih yang diujikan.

b. Laju Perkecambahan

Laju perkecambahan dihitung dengan menggunakan rumus menurut Sadjad dkk (1988) sebagai berikut:

$$
\mathrm{LP}=\frac{\mathrm{N} 1 \mathrm{~T} 1+\mathrm{N} 2 \mathrm{~T} 2+\ldots+\mathrm{NXTX}}{\mathrm{JB}}
$$

Keterangan:

LP = Laju perkecambahan.

$\mathrm{N}=$ Jumlah benih yang berkecambah pada satuan waktu

$\mathrm{T}$ =Jumlah waktu antara pengujian awal sampai pengujian akhir pada interval tertentu.

JB = Jumlah benih yang berkecambah.

Parameter vigoritas yang diukur adalah keserempakan tumbuh benih (\%). Keserempakan tumbuh benih dihitung dengan menggunakan presentase kecambah normal kuat pada hari ke 4. Menurut Sadjad (1993) parameter vigoritas dapat dihitung dengan rumus sebagai berikut [14]:

$$
\underline{\mathrm{KK}}
$$


Keterangan:

Kst $\quad=$ Keserempakan tumbuh

KK = Jumlah kecambah normal kuat

$\mathrm{TB}=$ Total benih yang dianalisis

\section{Rancangan Penelitian}

Penelitian ini dirancang dengan menggunakan Rancangan Acak Lengkap (RAL). Rancangan Acak Lengkap yang disusun dengan percobaan faktorial yang terdiri dari 1 faktor. Faktor pertama adalah pemberian dosis iradiasi sinar gamma yang terdiri dari 4 tingkatan yaitu 0 Gy, $100 \mathrm{~Gy}, 200 \mathrm{~Gy}$ dan $300 \mathrm{~Gy}$. Setiap perlakuan dikombinasikan dengan 5 ulangan.

\section{Analisis Data}

Data dianalisis dengan analisis keragaman ANOVA One Way untuk mengetahui pengaruh faktor perlakuan iradiasi sinar gamma terhadap vigor dan viabilitas benih.

\section{HASIL DAN PEMBAHASAN}

Pengukuran vigoritas dan viabilitas digunakan sebagai indikator penting terkait dengan kualitas benih. Vigoritas digambarkan melalui kekuatan tumbuh benih, secara fisiologis benih tersebut dapat tumbuh menjadi normal meskipun keadaan dilapangan tidak optimal [15]. Sedangkan viabilitas benih diartikan sebagai kemampuan benih untuk tumbuh menjadi kecambah yang dapat ditunjukkan melalui gejala metabolisme atau gejala pertumbuhan [16].

Pada pengujian ini didapatkan persentase benih normal, benih abnormal, dan benih segar tidak tumbuh (Gambar 1). Ciri benih normal adalah memiliki akar primer yang kuat dan panjang, plumula berwarna hijau, perkembangan hipokotil sempurna, benih abnormal tidak memiliki akar primer, plumula membusuk, sedangkan ciri benih segar tidak tumbuh adalah benih yang tidak tumbuh sampai akhir dari pengujian, tetapi masih mempunyai kemampuan untuk tumbuh menjadi normal. Benih jenis ini mampu menyerap air selama proses pengujian tetapi mengalami hambatan untuk proses perkembangan selanjutnya [13].

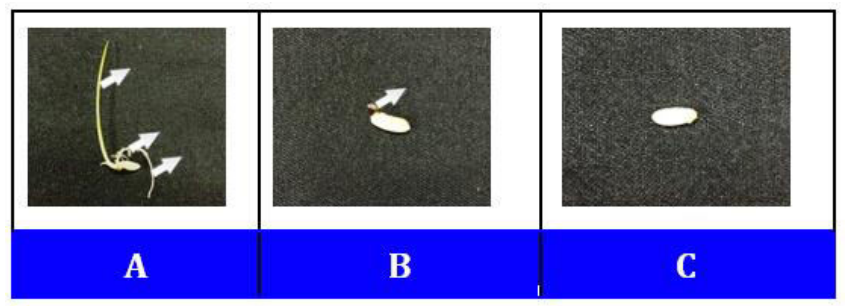

Gambar 1. Macam kategori kecambah.

Keterangan: A) Kecambah normal. B) Kecambah abnormal. C) Benih segar tidak tumbuh. D) Plumula sehat. E) Akar sekunder. F) Akar primer. G) Plumula abnormal.

Efek awal timbulnya mutasi pada suatu tanaman dapat dilihat melalui perkecambahan. Radiasi menyebabkan kerusakan pada tingkat kromosom dan DNA benih yang akan mempengaruhi fisiologis dan biokimia pada tanaman. Semakin tinggi dosis iradiasi yang diberikan maka benih akan mengalami peningkatan kadar protein dan penurunan kadar karbohidrat total serta energi total. Kadar karbohidrat dan energi total yang rendah membuat kecambah menjadi abnormal dan proses perkecambahan menjadi terhambat [16].
Menurut Amjad dan Akbar [17] pada percobaan iradiasi pada benih Allium cepa L. iradiasi pada dosis tinggi menyebabkan persentase bibit abnormal meningkat seiring dengan peningkatan dosis iradiasi.

Berdasarkan SNI 01-6233.3-2015 daya berkecambah padi memiliki batas minimum sebesar $80 \%$ sehingga dapat dikatakan benih padi varietas lokal SiGadis pada dosis 0 Gy (kontrol) dan dosis 100 Gy masih dalam batas strandar ketentuan SNI (Tabel 1). Sedangkan pada dosis 200 Gy dan $300 \mathrm{~Gy}$, memiliki hasil daya berkecambah dibawah batas minimum SNI. SNI 01-6233.3-2015 digunakan sebagai acuan normatif, syarat mutu dan rekomendasi untuk benih padi.

Tabel 1.

Pengaruh Dosis Iradiasi terhadap parameter daya berkecambah, laju perkecambahan dan keserempakan tumbuh benih padi Varietas SiGadis

\begin{tabular}{|c|c|c|c|}
\hline \multirow{2}{*}{$\begin{array}{l}\text { Dosis } \\
\text { Iradiasi } \\
(\mathrm{Gy})\end{array}$} & \multicolumn{3}{|c|}{ Parameter } \\
\hline & $\begin{array}{c}\text { Daya } \\
\text { Berkecambah } \\
(\%)\end{array}$ & $\begin{array}{c}\text { Laju } \\
\text { Perkecambahan } \\
\text { (Hari) }\end{array}$ & $\begin{array}{c}\text { Keserempakan } \\
\text { Tumbuh } \\
(\%)\end{array}$ \\
\hline 0 & $80 \mathrm{a}$ & $4 a$ & $80 a$ \\
\hline 100 & $80 \mathrm{a}$ & $4 a$ & $80 a$ \\
\hline 200 & $70 \mathrm{a}$ & $4 a$ & $70 \mathrm{a}$ \\
\hline 300 & $60 \mathrm{a}$ & $4 a$ & $60 \mathrm{a}$ \\
\hline
\end{tabular}

Keterangan: angka-angka yang diikuti huruf yang berbeda pada kolom yang sama menunjukkan beda nyata berdasarkan uji DMRT 5\%

Rerata daya berkecambah yang terdapat pada Tabel 1 menunjukkan bahwa peningkatan dosis iradiasi memberikan pengaruh yang tidak berbeda nyata (nilai $p=0.152$; taraf 5\%) pada persentase daya berkecambah padi varietas lokal SiGadis selama tujuh hari masa inkubasi. Daya berkecambah benih padi varietas lokal SiGadis memperlihatkan hasil yang beragam dimana pada dosis 0 Gy (kontrol) dan dosis 100 Gy didapatkan hasil yang sama yaitu sebesar $80 \%$, sedangkan penurunan daya berkecambah diperlihatkan pada dosis $200 \mathrm{~Gy}$ dan 300 Gy dengan hasil yaitu 70\% dan 60\% (Tabel 1). Menurut Kumar et al. [18]; Marcu et al. [19]; Sasikala et al. [20] meningkatnya dosis iradiasi yang diberikan pada benih padi, maka akan menurunkan daya berkecambah benih.

Penurunan daya perkecambahan benih dapat dipengaruhi oleh pemberian dosis tinggi iradiasi sinar gamma karena iradiasi elektromagnetik memiliki kemampuan untuk mempengaruhi elektron pada nukleus, sehingga mengubah ion normal menjadi positif dan melepaskan energi (ionisasi) saat melewati jaringan. Efek utama iradiasi ini adalah ionisasi air, yang dapat membentuk radikal hidroksil yang sangat reaktif. Reaksi radikal ini dapat mempengaruhi perubahan kimiawi dan dapat langsung bereaksi dengan semua molekul organik baik secara struktur maupun fungsional sehingga metabolisme menurun dan terjadi penurunan daya berkecambah [18][21].

Salah satu perubahan fungsional yang terjadi akibat iradiasi sinar gamma adalah penurunan aktivitas $\alpha$-amylase, sehingga terjadi penghambatan perkecambahan [18]. Selain itu hal ini juga berhubungan dengan permeabilitas membran pada benih, menurut Juhanda et al. [22] benih padi yang memiliki membran yang permeabel memungkinkan air dan gas dapat masuk ke dalam benih sehingga proses imbibisi dapat terjadi 
sehingga perkecambahan dapat terjadi dengan baik. Peningkatan dosis iradiasi sinar gamma juga dapat menurunkan permeabilitas membran pada benih sehingga dapat menurunkan daya berkecambah benih.

Induksi iradiasi sinar gamma juga dilaporkan dapat menginduksi stres oksidatif yaitu dengan memproduksi reaksi oksidatif spesies (ROS) seperti radikal superoksida, yang bereaksi pada semua molekul organik baik secara struktural dan fungsional. Untuk menghindari kerusakan oksidatif, tanaman akan mengembangkan berbagai mekanisme perlindungan di dalam sel [23]. Proses pertahanan ini akan membentuk perubahan pola ekspresi gen [24].

Reaksi Oksidatif Spesies (ROS) dalam konsentrasi yang rendah berperan dalam fungsi fisiologi tanaman, seperti pertumbuhan dan perkembangan tanaman, daya berkecambah, pertumbuhan akar, dan gravitropisme [25][26], dan [27]. Bahin et al. [28] melaporkan bahwa persinyalan sintesis giberelin (GA) pada benih barley dalam konsentrasi ROS yang rendah akan menurun dan meningkatkan sintesis ABA sehingga menyebabkan dormansi. Dalam hal ini $\mathrm{H}_{2} \mathrm{O}_{2}$ eksogen tidak mengubah biosintesis dan pensinyalan $\mathrm{ABA}$, namun memiliki efek yang lebih terliat pada persinyalan GA dan menyebabkan perubahan keseimbangan hormon yang menyebabkan perkecambahan.

Reaksi Oksidatif Spesies (ROS) dalam konsentrasi yang tinggi menyebabkan kerusakan oksidatif terhadap DNA nuklear, mitokondria dan kloroplas. Reaksi oksidatif menyebabkan kerusakan pada deoxyribose, nukleotida, dan dapat terbentuk variasi modifikasi pada nukleotida. Perubahan nukleotida dari satu untai dapat menyebabkan ketidakcocokan dengan nukleotida pada untai lainnya, dan menghasilkan mutasi [29].

Selain pengujian daya berkecambah, pengujian juga dilakukan terhadap laju perkecambahan. Rerata laju perkecambahan yang terdapat pada Tabel 1 menunjukkan bahwa peningkatan dosis iradiasi memberikan pengaruh yang tidak berbeda nyata (nilai $\mathrm{p}=0.118$; taraf 5\%) terhadap laju perkecambahan padi varietas lokal SiGadis selama 7 hari masa inkubasi. Berdasarkan rerata laju perkecambahan benih padi varietas lokal SiGadis (Tabel 1) dosis 0 Gy dan 300 Gy memerlukan waktu perkecambahan dalam 4 hari. Dosis 100 Gy memerlukan waktu perkecambahan dalam 4 hari 3 jam, sedangkan dosis 200 Gy memerlukan waktu perkecambahan dalam 4 hari 2 jam. Bila dibandingkan dengan kontrol, benih padi varietas SiGadis hasil iradiasi pada dosis 100 Gy dan 200 Gy membutuhkan 2 hingga 3 jam lebih lama untuk menumbuhkan radikula setelah perkecambahan.

Emrani et al. [30] melaporkan bahwa interaksi pemberian dosis tinggi iradiasi sinar gamma terhadap laju perkecambahan menunjukkan hasil yang lebih cepat dibanding dengan dosis yang lebih rendah pada tanaman jagung. Sehingga laju perkecambahan lebih cepat didapatkan pada dosis 200 Gy dan 300 Gy dibandingkan 100 Gy. Menurut Jia et al. [31] penurunan laju perkecambahan pada kedelai disebabkan akibat pemberian iradiasi sinar gamma, hal ini memicu penurunan pembelahan sel, sintesis hormon, terganggunya transportasi nutrisi keseluruh bagian tanaman, dan adanya gangguan metabolisme pada apikal meristem.

Iradiasi dapat meningkatkan sensitivitas tanaman. Menurut Nepal, et al., [32] iradiasi meningkatkan sensitivitas tanaman dengan mereduksi jumlah zat pengatur tumbuh endogenus terutama sitokinin dengan cara mendegradasi atau menurunkan tingkat sintesisnya. Iradiasi sinar gamma tidak secara langsung menurunkan akumulasi sitokinin, namun iradiasi mempengaruhi degradasi sel dan sintesis sitokinin. Berdasarkan [33] sintesis sitokinin membutuhkan fungsi optimal dari organel sel mitokondria untuk menghasilkan ATP dan menyediakan kalsium sehingga m-RNA dapat berperan sebagai template sintesisnya. Iradiasi dapat mendegradasi mitokondria dan nukleus karena membran sel dan membran nukleus sensitif terhadap paparan iradiasi, namun sitokonin yang telah diakumulasi dalam granula tidak akan mengalami degradasi karena granula memiliki struktur sel yang resisten terhadap iradiasi.

Setelah dilakukan pengujian terhadap viabilitas benih, pengujian dilakukan terhadap vigoritas benih. Keserempakan tumbuh benih merupakan satu parameter pengujian vigoritas benih. Tingkat vigoritas yang tinggi dapat dilihat dari kecambah yang toleran terhadap berbagai faktor pembatas yang mempengaruhi pertumbuhan dan perkembangannya [14]. Menurut Surya [34], semakin tinggi pemberian dosis iradiasi maka secara umum akan menyebabkan kerusakan fisiologi dalam benih tersebut sehingga vigoritas benih tersebut akan menurun. Hal ini merupakan pengaruh hormesis sebagai penghambatan pertumbuhan tanaman pada iradiasi dosis yang tinggi [35].

Rerata keserempakan tumbuh yang terdapat pada Tabel 1 menunjukkan bahwa peningkatan dosis iradiasi memberikan pengaruh yang tidak berbeda nyata (nilai $\mathrm{p}=0.152$; taraf $5 \%$ ) terhadap persentase perkecambahan padi varietas lokal SiGadis selama 7 hari masa inkubasi. Hasil rerata yang sama didapatkan pada dosis 0 Gy (kontrol) dan dosis 100 Gy yaitu sebesar $80 \%$, sedangkan penurunan daya berkecambah diperlihatkan pada dosis 200 Gy dan 300 Gy dengan hasil yaitu $70 \%$ dan $60 \%$.

Pemberian dosis tinggi iradiasi sinar gamma dapat menurunkan keserempakan tumbuh. Pemberian iradiasi sinar gamma dapat mempengaruhi karakter fisiologis, hal ini juga disebabkan karena adanya radikal bebas dari penyinaran sinar gamma [36]. Keserempakan tumbuh mengindikasikan bahwa tanaman tersebut tumbuh serempak, seragam dan lebih vigor dalam perlakuan cekaman. Sehingga pada pertumbuhan selanjutnya dapat menghasilkan tanaman lebih toleran terhadap stress dan meningkatkan hasil tanaman.

Benih yang memiliki nilai vigor yang rendah umumnya disebabkan benih tidak mampu memanfaatkan energi untuk metabolisme dibandingkan dengan benih yang memiliki nilai vigor tinggi. Menurut Syafruddin dan Miranda [37], vigor benih yang tinggi menyebabkan benih toleran dan berkembang pada kondisi lahan yang sub-optimum, berupa lingkungan yang kurang sesuai untuk pertumbuhan dan perkecambahan benih.

Penurunan tingkat keserempakan tumbuh benih berkaitan dengan pengaruh umum iradiasi yang sering ditunjukkan dengan kerusakan fisiologis seperti hambatan pertumbuhan, kematian dan sterilitas tanaman [34]. Selain kerusakan fisiologis, terdapat efek deterministik akibat iradiasi sinar gamma. Menurut Utami [38] efek deterministik adalah efek yang disebabkan karena kematian sel akibat paparan radiasi. Efek deterministik terjadi apabila dosis yang diterima tanaman 
diatas dosis ambang (threshold dose) dan umumnya timbul beberapa saat setelah iradiasi. Tingkat keparahan efek deterministik akan meningkat bila dosis yang diterima lebih besar dari dosis ambang.

\section{KESIMPULAN}

Iradiasi sinar gamma pada benih tanaman padi varietas SiGadis memberikan pengaruh yang tidak signifikan. Peningkatan dosis iradiasi menurunkan daya berkecambah dan keserempakan tumbuh benih. Sampel kontrol dan 100 Gy didapatkan hasil yang sama yaitu sebesar $80 \%$, sedangkan 200 Gy dan 300 Gy terjadi penurunan secara berturut-turut sebesar $70 \%$ dan $60 \%$. Sedangkan parameter laju perkecambahan kontrol dan perlakuan 300 Gy didapatkan hasil yang sama yaitu selama 4 hari, sedangkan pada 200 Gy selama 4 hari 20 menit dan 100 Gy didapatkan hasil yang paling lama yaitu 4 hari 30 menit.

\section{DAFTAR PUSTAKA}

[1] Purwanto and H. Purnamawati, Budidaya 8 Jenis Tanaman Pangan Unggul. Jakarta: Penebar Swadaya, 2009.

[2] M. Umadevi, R. Pushpa, K. P. Sampathkumar, and D. Bhowmik, "Rice Traditional Medicinal Plant in India," J. Pharmacogn. Phytochem., vol. 1, no. 1, pp. 6-12, 2012.

[3] A. S. Romdon, E. Kurniyati, S. Bahri, and J. Pramono, "Deskripsi Varietas Padi," 2014.

[4] G. S. Chahal and S. S. Gosal, "Mutation Breeding. In Principles and Procedure of Plant Breeding," Biotechnol. Conv. Approaches, p. 604, 2006.

[5] E. Wijananto, "Radiasi dan Ketahanan Pangan," Jakarta, 2012.

[6] D. Ermavitalinia, I. P. Sari, E. N. Prasetyo, N. Abdulgani, and T. B. Saputro, "Effect of Gamma 60Co Irradiation On The Lipid Content and Fatty Acid Composition of Nannochloropsis sp. Microalgae," in Proceeding of International Biology Conference, 2016.

[7] Y. C. F. Salsinha, "Pengaruh Iradiasi Sinar $\Gamma$ (Gamma) Co-60 Terhadap Pertumbuhan Padi (Oryza Sativa) 'Situ Bagendit' Pada Cekaman Kekeringan,” Pap. J. Fak. Biol., 2015.

[8] T. B. Saputro, F. Finariyah, S. DIanawati, N. F. Sholihah, and D. Ermavitalini, "In vitro selection of local maize (Zea mays) on $\mathrm{NaCl}$ stress and its genetic characterization using RAPD," J. Biol. Biol. Educ., vol. 8, no. 3, pp. 344-351, 2016.

[9] T. Saputro, N. Fadillatus., and E. Dini, "Dynamics Expression Of Osr40c1 Gene And Growth Of Maize (Zea Mays) Calluses In Responding To Salt Stress," Biodiversitas, vol. 18, no. 2, pp. 801-808, 2017.

[10]N. F. Sholihah and T.B. Saputro, "In vitro selection of maize (Zea mays L.) varietas Talango and Manding to Salinity Stress," J. Sains dan Seni ITS, vol. 4, no. 1, pp. E60-E63, 2016.

[11] M. K. Lesilolo and dan E. A. M. J. Riry, "Pengujian Viabilitas dan Vigor Benih Beberapa Jenis Tanaman yang Beredar di Pasaran Kota Ambon," Agrogolia, vol. 2, no. 1, pp. 1-9, 2013.

[12] J. Kartahadimaja and E. Erlinda, "Pengaruh Penyimpanan Jangka Panjang (Long Term) terhadap Viabilitas dan Vigor Empat Galur Benih Inbre Jagung," J. Penelit. Pertan. Terap., vol. 13, no. 3, pp. 168-173, 2013.

[13]H. Purnobasuki, "Kadar Benih," 2011. [Online]. Available: http://skp.unair.ac.id/repository/GuruIndonesia/KadarBenih_HeryPurnobasuki_236.pdf.

[14] S. Sadjad, Dari Benih Kepada Benih. Jakarta: PT. Grasindo, 1993.

[15]C. I. Nur, "Uji Viabilitas dan Vigor Benih Beberapa Varietas Padi (Oryza sativa L.) yang Diproduksi pada Temperatur yang Berbeda Selama Kemasakan," J. Floratek, vol. 2, pp. 37-42, 2006

[16]D. J. Sudrajat and M. Zanzibar, "Prospek Teknologi Radiasi Sinar Gamma Dalam Peningkatan Mutu Benih Tanaman Hutan," Info Benih, vol. 13, no. 1, pp. 158-163, 2009.

[17]M. Amjad and A. Akbar, "Effect of post-irradiation storage on the radiation- induced damage in onion seeds," Asian J. Plant Sci., vol. 2, no. 9, pp. 702-707, 2003.

[18]P. D. Kumar, A. Chatuverdi, M. Sreedhar, M. Aparna, P. Venu-Babu, and R.K. Singhal, "Gamma Radiosensitivity Study on Rice (Oryza sativa L.)," Asian J. Plant Sci. Res, vol. 3, no. 1, pp. 54-68, 2013.

[19]D. Marcu, V. Cristea, and L. Daraban, "Dose-dependent effects of gamma radiation on lettuce (Lactuca sativa var. capitata) seedlings," Int. J. Radiat. Biol., pp. 1-5, 2012.

[20]R. Sasikala and R. Kalaiyarasi, "Sencitivity of Rice Varieties to Gamma Irradiation," Electron. J. Plant Breed., vol. 1, no. 4, pp. 885-889, 2010.

[21]F. O. Olakunle, I. C. Olumuyiwa, B. Peter, and S. Bado, "Mutagenic Effects of Gamma Radiation on Eight Accessions of Cowpea (Vigna unguiculata [L.] Walp.)," Am. J. Plant Sci., vol. 7, pp. 339-351, 2016.

[22]Juhanda, Y. Nurmiaty, and Ermawati, "Pengaruh Skarifikasi pada Pola Imbibisi dan Perkecambahan Benih Saga Manis (Abruss precator L.)," $J$. Agrotek Trop., vol. 1, no. 1, pp. 45-49, 2013.

[23] L. A. P. Kiong, J. Y. i Chia, S. Hussein, and A. R. Harun, "Physiological Responses of Citrus sinensis to Gamma Irradiatio," World Appl. Sci. J., vol. 5, no. 1, pp. 1-12, 2008.

[24]E. Borzouei, M. Kafi, H. Khazaei, B. Naseriyan, and Majdabadi, "Effects of Gamma radiation on germination and physiological aspects of wheat (Triticum aestivum L.) seedlings," Pak. J. Bot, vol. 42, no. 4, pp. 22812290, 2010.

[25]R. Mittler, S. Vanderauwera, N. Suzuki, G. Miller, V.B.Tognetti, and K. Vandepoele, "ROS signaling: the new wave," Trends Plant Sci, vol. 16, pp. 300-309, 2011

[26]M. Wrzaczek, M. Brosche, and J. Kangasjarvi, "ROS signaling loops: production, perception, regulation," Curr. Opin. Plant Biol, vol. 16, pp. 575-582, 2013.

[27]A. Baxter, R. Mittler, and N. Suzuki, "ROS as key players in plant stress signalling," J. Exp. Bot, vol. 65, pp. 1229-1240, 2014.

[28]E. Bahin, C. Bailly, B. Sotta, I. Kranner, F. Corbineau, and J. Leymarie, "Crosstalk between reactive oxygen species and hormonal signalling pathways regulates grain dormancy in barley," Plant, Cell Environ., vol. 34, no. 6, pp. 980- 993, 2011.

[29]P. Sharma, A. B. Jha, R. S. Dubey, and M. Pessarakli, "Reactive oxygen species, oxidative damage and anti-oxidative defense mechanism in plants under stressful conditions," J. Bot., pp. 1-26, 2012.

[30]D. A. Emrani, A. Razavi, and Dr. M. Farhad, "Assessment of Gamma Ray Irradiation Effects on Germination and Some Morphological Characters in Tow Corn Cultivars," Int. J. Agric. Crop Sci., vol. 5, no. 11, pp. 1235-1244, 2013.

[31]C. Jia and A. Li, "Effect of gamma radiation on mutant induction of Fagopyrum dibotrys Hara," Photosynthetica, vol. 46, pp. 363-369, 2008.

[32] S. Nepal, B. R. Ojha, A. J. S. Meador, S. P. Gaire, and C. Shilpakar, "Effect of Gamma Rays on Germination and Photosynthetic Pigments of Maize (Zea mays L.) Inbreds," Int. J. Res., vol. 1, no. 5, pp. 511 - 525, 2014.

[33] Shukla et al., "Effect of Gamma Irradiation on Cytokines Released by Planlets During Storage," J. Radiat. Res. Appl. Sci., vol. 9, pp. 15 - 19, 2016.

[34]M. I. Surya and H. Soeranto, "Pengaruh Iradiasi Sinar Gamma terhadap Pertumbuhan Sorgum Manis (Sorghum bicolor L.)," in Risalah Seminar Ilmiah Aplikasi Isotop dan Radiasi, 2006, pp. 209-215.

[35]T. Luckey, "Radiation Hormesis Overview," RSO Mag., vol. 4, pp. 1936, 2003.

[36]I. Kovalchuk, J. Molinier, Y. Yao, A. Arkhipov, and O. Kovalchuk, "Transcriptome analysis reveals fundamental differences in plant response to acute and chronic exposure to ionizing radiation," Mutat. Res., vol. 624, pp. 101-113, 1007.

[37] Syafruddin and T. Miranda, "Vigor Benih Beberapa Varietas Jagung pada Media Tanam Tercemar Hidrokarbon," J. Floratek, vol. 10, pp. 18-25, 2015.

[38]S. Utami, "Uji Viabilitas dan Vigoritas Benih Padi Lokal Ramos Adaptif Deli Serdang dengan Berbagai Tingkat Dosis Iradiasi Sinar Gamma di Persemaian," Agrium, vol. 18, no. 2, pp. 158 - 161, 2012. 